\title{
The role of managerial characteristics in FX risk management: Who increases risk?
}

\section{Andreas Hecht ${ }^{1}$ (i)}

Received: 9 October 2019 / Accepted: 30 November 2020 / Published online: 4 January 2021

(c) The Author(s) 2020

\begin{abstract}
We examine the impact of managerial characteristics on the choice of risk-decreasing and risk-increasing/-constant strategies. Using unique data on firm-, year-, and currency-specific FX exposure before and after hedging with corresponding hedging instruments, we are able to measure how much a CEO has been involved in riskincreasing/-constant strategies over several years. We provide evidence that firms where the CEO has an MBA degree and is older are more likely to engage in riskincreasing/-constant strategies. In addition, we find that a CEO's affiliation to the owner's family seems to reduce the amount of derivatives a firms uses, while hedging short tends to increase derivative volumes.
\end{abstract}

Keywords Foreign exchange $\cdot$ Derivatives $\cdot$ Risk management $\cdot$ Speculation $\cdot$ Managerial characteristics

JEL Classification G30 • G32 • G39

\section{Introduction}

Firms use derivative instruments to decrease or increase their risk exposure, or in other words, these financial contracts are used for hedging or speculative purposes in corporate risk management (e.g., Allayannis and Ofek 2001; Géczy et al. 2007; Hecht 2019; Hecht and Lampenius 2019; Hentschel and Kothari 2001). While the literature on the determinants of hedging and speculative strategies traditionally focused on firm characteristics, several recent studies indicate the influence of managerial characteristics on risk management choices. This 'behavioral' stream in literature provides empirical evidence that managerial characteristics of executives affect a wide range of corporate practices, such as diversification, cost reduction

Andreas Hecht

hecht.andreas@uni-hohenheim.de

1 Institute of Financial Management, University of Hohenheim, Schwerzstrasse 42,

70599 Stuttgart, Germany 
or investment and financial strategies (e.g., Bertrand and Schoar 2003; Malmendier and Tate 2005; Malmendier et al. 2011). More recently, several studies examine the role of personal characteristics in corporate risk management (e.g., Beber and Fabbri 2012; Doukas and Mandal 2018; Entrop and Merkel 2018; Géczy et al. 2007), with a focus on hedging and the notional amount of derivatives employed as response variable. Common to these studies is the usage of proxies for exposure and derivative usage. Building on their hedging results to exclude fundamental hedging motives, Beber and Fabbri (2012) and Entrop and Merkel (2018) also relate managerial characteristics to corporate speculation, where they interpret speculation as variation in the derivatives position, often referred to as selective hedging. ${ }^{1}$

Another stream of the literature refers to speculation as activity that increases or fails to decrease the exposure (e.g., Allayannis and Ofek 2001; Hentschel and Kothari 2001; Zhang 2009). In the present paper, we follow this definition of speculation and use a new dataset with reported firm-, year- and currency-specific information on the exposure before and after hedging to examine the unexplored impact of managerial characteristics on the choice of risk-decreasing and risk-increasing/constant strategies. While previous articles predominantly rely on 1-year data for currency hedging, ${ }^{2}$ we study the influence of managerial characteristics over a period of 6 years for FX risk management. Further, unlike most studies, we study both the impact of CEO and CFO characteristics, since several studies show the relevance of both executives, and we investigate whether family ties play a role in the choice of risk-decreasing and risk-increasing/-constant strategies.

In this context, we exploit the unexamined regulatory environment of France with its innovative disclosures on corporate risk management activities. Based on the advanced data with information on firm-, year- and currency-specific exposure before and after hedging with associated hedged amounts on corporate FX risk management activities, we are able to separate risk-decreasing from risk-increasing/constant activities. In accordance with the literature's denomination (e.g., Allayannis and Ofek 2001; Hentschel and Kothari 2001; Zhang 2009), we define positions that [fail to] decrease the exposure as hedging [speculation]. Using this information as response variable in our hand-collected dataset from 2010 to 2015, we find that firms tend to engage in more risk-increasing/-constant activities when the CEOs holds an MBA degree. The data granularity and our 6-year sample period further allows us to measure how much a specific firm or even manager has engaged in risk-increasing/-constant strategies over several years. Using these specifications as new output variables, we observe that the managerial characteristics considerably increase the explanatory power of our model by 83 and $123 \%$ in relation to only firm characteristics. We find again that firms where the CEO holds an MBA degree are

\footnotetext{
1 Selective hedging refer to the sizing and timing of derivative transactions based on individual market views (e.g., Adam et al. 2015; Glaum 2002; Stulz 1996). Beber and Fabbri (2012) and Entrop and Merkel (2018) measure speculation as firm-specific standard deviation of estimated residuals of a regression with firm characteristics.

2 To our knowledge, Doukas and Mandal (2018) is the only study that examines a 5-year period, but focuses on hedging using proxy variables for exposure and derivative usage.
} 
more likely to manage their exposure with speculative methods, as well as provide empirical evidence that older CEOs tend to speculate more. For CFOs, however, we do not find any correlations between (the extent of) risk-increasing/-constant strategies and personal characteristics. As potential explanation we illustrate that the position of the CEO in France seems to be stronger compared to the Anglo-Saxon environment, which might be the reason for the CEO's influence on risk management strategies.

In addition, we investigate how personal characteristics influence derivative usage, but unlike the extant literature we use actually reported volumes instead of proxy variables with potential estimation errors. We use the firm-, year and currency-specific amount of hedging instruments that can be either short or long. We find that firms tend to use less hedging instruments when the CEOs is older and holds an MBA degree. Further, according to agency theory, family CEOs might be discouraged to engage in risky activities compared to nonfamily CEOs. In our analysis, we find that for a CEO with family ties to the owner's family, the amount of derivatives used tends to decrease, which could imply leaving positions unhedged. However, we do not interpret the mere reduction in the volume of derivatives as indicator for an increased risk appetite, especially as we could not find significant relationships for family CEOs when analysing the choice of risk-decreasing and riskincreasing/-constant strategies. Finally, the advantage in data granularity enables us to examine whether the direction of the hedging instruments, i.e., long or short, affect the volume of derivatives a firm uses. We find indeed that when firms use predominantly short hedging instruments, they are more likely to use higher volumes.

As we use data from a European setting, we also investigate the differences of MBA and PhD education. Entrop and Merkel (2018) argue that in continental Europe and especially German-speaking countries, a $\mathrm{PhD}$ as highest degree in research is more prestigious and prevalent among executives than an MBA degree. When using the $\mathrm{PhD}$ instead of the MBA variable, we observe the same relationships with similar magnitude, i.e., we do not find differences for MBA or PhD education in relation to the risk management decision-making.

We contribute to the growing literature on the relevance of managerial characteristics in risk management decisions in two ways. First, based on the data granularity of the dataset we are able to differentiate between currency positions that decrease, increase or keep the FX exposure constant and define speculation [hedging] as riskincreasing/-constant [risk-decreasing] strategy. We complement the literature when relating managerial characteristics to risk-decreasing and risk-increasing/-constant strategies. Further, as we analyze a 6-year time period, we are able to estimate the extent of how much a particular executive has engaged in risk-decreasing vs riskincreasing/-constant strategies over several years. This variable enables us to measure the managerial impact on risk management more precisely. Second, we add new features to the analysis of the managerial effect on hedging decisions. Our dataset allows the unprecedented differentiation of long and short derivative positions and we provide evidence that hedging short might lead to higher derivative volumes. Further, we find that the affiliation to the owner's family may affect derivative usage and that there is no difference between MBA and PhD education in terms of the impact on risk management. 
The paper is structured as follows. Section 2 presents the structure of the reported data and describes our sample. Section 3 discusses the role of managerial and firm characteristics in the literature and describes the empirical setting. Section 4 presents and discusses the empirical results. Section 5 concludes.

\section{Data and sample description}

\subsection{Data description}

To verify the impact of managerial characteristics on the choice of risk-decreasing and risk-increasing/-constant strategies, we explore the unique regulatory environment of France. Here, the financial markets' authority, the Autorite des Marchés Financiers (AMF), advises firms to disclose additional information regarding the management of FX risks via an optional supplement, the so-called 'registration document'. ${ }^{3}$ This document aims at "providing the market with comprehensive, consolidated annual information and providing companies with access to a faster approval procedure when they include this document within a prospectus". ${ }^{4}$ In position paper n²009-16 (Autorité des Marchés Financiers 2009) in the FX reporting section, the AMF recommends risk management disclosures on exposures before and after hedging that by far exceed the specifications of IFRS 7.33 and 7.34. In analogy to Hecht and Lampenius (2019), "Appendix 1" illustrates the recommended format of FX information by the AMF.

As can be seen, the supervisor of the French financial markets advises firms to state their firm-, year-, and currency-specific FX exposure before and after hedging. Firms usually provide information about their assets and liabilities that are subject to FX risk (column [a] and [b] in "Appendix 1", mostly in form of FX-receivables and FX-payables). Together with the forecasted exposure (column [c]), these figures yield the firm-, year-, and currency-specific exposure before hedging (column [d]). In the registration document, firms also specify the amount of hedging instruments (column [e]) used to manage the corresponding exposure before hedging, together with the resulting net exposure after hedging (column [f]). The following numerical example illustrates the structure of the data: For a respective currency a firm has, at a point $t, 120$ units of FX-assets and 30 units of FX-liabilities. Together with the netted figure of 90 units, the firm reports forecasted FX-sales of 20 units and forecasted FX-purchases of 10 units, resulting in an exposure before hedging of 100 $(120-30+20-10=100)$ units. If the firm uses 50 units of hedging instruments to hedge this exposure, the exposure after hedging amounts to $50(100-50)$ units.

Since we are particularly interested in whether firms decrease or increase their FX risk with derivative transactions, we use the reported information on exposure before and after hedging to assess a firm's FX-strategy. We do so by calculating

\footnotetext{
3 It should be noted that the reference document has been replaced since July 2019 by the universal registration document resulting from EU Regulation 2017/1129 of June 14, 2017. The content of this new document is largely inspired by the French reference document.

${ }^{4}$ https://www.amf-france.org/en/news-publications/news/revision-prospectus-directive.
} 
firm-, year- and currency-specific hedge ratios $(H R)$, i.e., the percentage of FX exposure covered by derivative instruments. In line with Hecht (2019) and Hecht and Lampenius (2019), we define the hedge ratio in $t\left(H R_{t}\right)$ as $H R_{t}=H_{t} / \mathrm{E}_{t}^{b}$, where $H_{t}$ denotes the hedging instruments and $E_{t}^{b}$ the exposure before hedging in $t$. Note that both the hedging instruments, i.e., nominal volumes, $(H)$ and the exposure before hedging $\left(E^{b}\right)$ can be long and short, i.e., positive and negative, consequently also $H R$ can take positive and negative values. The combination of the hedging instruments (numerator) and the exposure before hedging (denominator) in the hedge ratio is exemplified in "Appendix 2", together with the six fundamentally different positions a firm may take with hedging instruments. It becomes clear that-in dependence on the amount of hedging instrument and the deduced exposure after hedging, two positions each can be classified as risk-decreasing, risk-increasing and risk-constant strategies. While risk-decreasing strategies lower the exposure with $-2<H R<0$, risk-increasing strategies raise the exposure with $H R<-2$ or $H R>0$, and risk-constant strategies keep the exposure constant with $H R=-2^{5}$ or $H R=0$. Overall, the different ranges illustrate the discontinuous nature of the hedge ratio in terms of riskincreasing and risk-decreasing. Between the hedge ratio range of $-2<H R<-1$, the overhedging changes the sign of the exposure, which could be a sign for speculative intentions. However, Hecht and Lampenius (2019) demonstrate that these positions have a mean of HR -1.18 and attribute this only slight under-/overhedging to imperfect hedge conditions in the real world (Hull 2015), which is why we classify such positions as risk-decreasing. Within the limits of $-2<H R<0$ market views in the context of selective hedging (e.g., Adam et al. 2015; Beber and Fabbri 2012; Glaum 2002) may also be included in the hedging decision, but due to the general reduction of the exposure, we classify this strategy as risk-decreasing and therefore clearly distinguish it from a risk-increasing or a risk-constant strategy. In line with the literature (e.g., Allayannis and Ofek 2001; Hentschel and Kothari 2001; Zhang 2009), we use the terms 'hedging' and 'speculation' as synonyms for risk-decreasing and risk-increasing/-constant strategies, respectively. While Allayannis and Ofek (2001) and Hentschel and Kothari (2001) investigate the sensitivity of stock return and employ the term 'hedging' and 'speculation' for risk-decreasing and riskincreasing strategies, Zhang (2009) categorizes firms that lower their expected risk exposure as 'effective hedgers' and firms that fail to lower their expected risk exposure as 'ineffective hedgers/speculators'. 6

Table 1 illustrates the number of observations for risk-decreasing, risk-increasing and risk-constant positions. ${ }^{7}$

\footnotetext{
${ }^{5} H R=-2$ (only three observations) keeps the size of the risk exposure constant, but the direction of exposure changes.

${ }^{6}$ We have also tested for the possibility that different speculative positions aggregate to a hedged position. By combining all speculative positions per firm and year, we find no evidence that different speculative exposures and corresponding hedged amounts across several currencies aggregate to an overall hedged position.

${ }^{7}$ Hecht and Lampenius (2019) further review the number of risk-increasing observations to ensure that this is not an artifact of some error in reporting.
} 


\subsection{Sample description}

The French financial markets' authority, the AMF, published the position paper with the guidelines on the elaboration of the registration document in December 2009. Consequently, the year 2010 marks the starting point of our panel dataset that initially encompasses all 333 French firms listed in the CAC All-Tradable index as of April 2016. Consistent with the extant literature (e.g., Beber and Fabbri 2012; Géczy et al. 2007), we exclude financial firms (18) due to their different business model and motivation for derivative usage. For the remaining firms, we hand-collect the reported FX exposure and hedging information. We drop firms that do not face any (or no significant) FX exposure (183) and firms that do not comply with the recommendation of the AMF and hence do not provide the advanced data granularity (70). ${ }^{8}$ Due to the voluntary nature of the additional disclosures, our results may be subject to a potential selection bias. However, the high direct cost of compliance ${ }^{9}$ with the recommendations of the AMF seem to explain why some firms are unwilling to pay these high costs of reporting even if they handle their exposures similarly. Following Adam et al. (2015), we restrict our sample to active hedgers, i.e., we exclude firms that never use FX derivatives to hedge their existing exposure. Our final sample counts 1814 firm-year-currency observations for 62 firms from 53 industries (according to the four digit SIC code), and in total, we observe 48 different currencies, where every firm reports FX exposure in an average of 4.9 currencies. To determine the impact of managerial characteristics, we match this sample with personal and educational details of the CEOs and CFOs. Further, we control for fundamental firm characteristics obtained from the Compustat Global Vantage database. To eliminate data outliers, we winsorize all firm characteristics to the 1st and 99th percentile. Given that the firm-specific FX data and the managerial characteristics are hand-collected and all data points are meaningful, these variables are not winsorized.

Consistent with the extant literature (Bodnar et al. 1998; Giambona et al. 2018), our French sample firms mainly employ forward or future contracts, the use of options and swaps is reported less often. Recent survey evidence in France from Albouy and Dupuy (2017) confirms forward contracts as the by far leading FX hedging instrument. Similar to Allayannis and Ofek (2001) and Beber and Fabbri (2012) we exclude FX swaps from the analysis as they are often not used to hedge

\footnotetext{
${ }^{8}$ Some of these firms still provide more information as requested by the specifications of IFRS 7.33 and 7.34 (e.g., breakdown per currency) and thus partly follow the recommendations by the AMF, but not to the extent required for inclusion in our study. Other firms measure and control their FX risk using Value at Risk (VaR) and have therefore not provided exposure data before and after hedging. The number of 183 firms without (significant) FX exposure is plausible, since the CAC-All-Tradable index consists of a significant amount of small and medium sized enterprises (SME) that might not be exposed to FX risks.

9 The registration document is an additional, optional document to be submitted to the AMF that may facilitate the process of issuing public securities. As an example, one firm illustrates the difference between its annual report and registration document by showing that the registration document contains further essential details on the company's activity, financial situation and prospects.
} 
Table 1 Hedge ratio classification

\begin{tabular}{lllrl}
\hline Strategy & Hedge ratio & Impact on exposure & No. obs & Cum. obs. \\
\hline Risk-decreasing & $-2<H R<-1$ & Decrease & 260 & 260 \\
& $H R=-1$ & Decrease & 82 & 342 \\
& $-1<H R<0$ & Decrease & 759 & 1101 \\
Risk-increasing & $H R<-2$ & Increase & 65 & 1166 \\
& $0<H R$ & Increase & 159 & 1325 \\
Risk-constant & $H R=-2$ & Constant & 3 & 1328 \\
& $H R=0$ & Constant & 486 & 1814 \\
\hline
\end{tabular}

This table reports the hedge ratio classification, defined as the percentage of FX exposure covered by hedging instruments $\left(H R_{t}=H_{t} / \mathrm{E}_{t}^{b}\right)$, where $H_{t}$ and $E_{t}^{b}$ denote the hedging instruments and the exposure before hedging in $t$, respectively. $H R$ captures risk-decreasing, risk-increasing and risk-constant strategies where technically (a) risk-decreasing strategies lower a firm's FX exposure with $-2<H R<0$; (b) riskincreasing strategies raise a firm's FX exposure with $H R<-2$ or $H R>0$; (c) risk-constant strategies keep a firm's FX exposure stable with $H R=-2$ or $H R=0$

foreign sales, but to convert FX debt into domestic liabilities. ${ }^{10}$ We ignore all transaction costs associated with hedging activities and assume that currency markets are efficient in the weak sense of information efficiency (Fama 1970).

\section{The role of managerial and firm characteristics}

\subsection{Managerial characteristics and hypotheses development}

Traditional economic theories do not attach value to managers as individuals. Either they are assumed homogenous and hence perfectly interchangeable, or individuals are not able to shape corporate decision-making. The standard models, however, leave us with unexplained heterogeneity in corporate practices and the question why organizations act the way they do. One important approach that provides a theoretical foundation for the association of managerial characteristics and firm outcomes is the "Upper Echelon theory" (Hambrick and Mason 1984). It analyses the relationship between managerial backgrounds and corporate decision-making and indicates that organizational outcomes are partly predicted by managers' characteristics, their values and previous experiences. Following this popular model of how top management characteristics may become reflected in the results of an organisation, researchers started to investigate the relevance of managerial characteristics. Bertrand and Schoar (2003), amongst others, find that behavioral differences between managers matter for a broad spectrum of business decisions: For example, they document that executives systematically influence investment and financial practices. More

${ }^{10}$ If FX instruments are not further specified in the registration document, FX swaps may be included, but cannot be separated. However, since FX forward contracts are the most important currency hedging instruments, this should not lead to a systematic bias. 
recently, the corporate finance literature started studying the impact of managerial characteristics on corporate risk management decisions, building upon the overconfidence model of Gervais and Odean (2001) and other behavioral aspects from psychological and economic research. This stream of the extant literature illustrates how certain educational and personal characteristics of managers may translate into overconfidence. For example, the age and tenure of a CEO as well as MBA education have been shown to influence corporate risk management practices (e.g., Beber and Fabbri 2012; Doukas and Mandal 2018; Tufano 1996).

The model of Gervais and Odean (2001) demonstrates how overconfidence arises and how it evolves. The authors illustrate how traders falsely overweight the possibility that their success is based on superior skills. This tendency to overestimate the extent to which we are responsible for our own achievements describes an attribution bias in learning and results in overconfidence. Thus, a superior level of education may lead to overconfidence. As the MBA degree is presumably one of the highest degrees in general management, it is particularly often subject of intensive research. Bertrand and Schoar (2003) examine the impact of managerial characteristics and observe that executives with an MBA degree tend to engage in more aggressive activities. Beber and Fabbri (2012) relate CEO characteristics to corporate speculation (interpreted as variation in the derivatives position) and find that firms where the CEO has an MBA degree speculate more. Following the prediction of the overconfidence model of Gervais and Odean (2001), we therefore test the hypothesis $\mathrm{H} 1$ that managers with an MBA degree are more involved in risk-increasing/constant activities. We use a dummy variable 'MBA' that equals one if the manager holds an MBA degree and zero otherwise.

The attribution bias in Gervais and Odean (2001) described above develops at the beginning of a career and becomes weaker with increasing experience and age, when we are able to assess our abilities more realistically. In general, this means for our setting in corporate risk management that overconfidence can originate from or be impacted by other personal characteristics such as age or work experience, for which the empirical literature also documents their impact on risk-taking behavior (e.g., Beber and Fabbri 2012; Doukas and Mandal 2018; Entrop and Merkel 2018). ${ }^{11}$ Apart from overconfidence, these aspects also influence the level of risk aversion, qualification as well as career and reputation intentions-all conditions and circumstances that affect the incentives to hedge or speculate. For these reasons, we test the hypotheses $\mathrm{H} 2$ that younger managers are more involved in risk-increasing/-constant activities and $\mathrm{H} 3$ that managers with less work experience (within the current firm or in others before) are more involved in risk-increasing/-constant activities. Accordingly, we include the variables 'Age' measuring the age of the managers, 'Tenure' capturing the number of years the manager is in the current position, and 'Companies' measuring the number of companies that the manager has worked for before joining the current company.

\footnotetext{
11 Gender is another feature that may to influence managers' risk behavior. As all almost our entire sample contains only male observations, we do not include such a variable in our analysis. Further, we do not have access to executive compensation data through ExecuComp or comparable databases.
} 
Another personal feature that may affect the willingness to take risks is the CEO's affiliation to the owner's family, which implies that a firm is a family business. According to agency theory, a firm's ownership and management affect risk behavior. In family businesses, where only few people carry the financial burden, family CEOs generally have a high degree of ownership in the firm, which discourages risky activities (Fama and Jensen 1983; Jensen and Meckling 1976). Then again, others argue that when ownership increases, there is a greater agreement between the owner and the firm, which could encourage risk taking (Fama and Jensen 1983; Zahra 2005). This risk taking in the context of family business, however, rather refers to the exploration of innovative ideas and business models than to the risk-increasing activities with derivative transactions (Zahra 2005). ${ }^{12}$ Nonfamily CEOs, on the other hand, bear a lower financial burden and can establish themselves through riskier projects (Shleifer and Vishny 1989). In this respect, Huybrechts et al. (2013) also provide empirical evidence for a positive impact of nonfamily CEOs on the risk behavior of family businesses. ${ }^{13}$ We therefore test the hypothesis $\mathrm{H} 4$ that family managers are less involved in risk-increasing/-constant activities. To identify a family business, we employ the definition of the Euronext Family Business Index. ${ }^{14}$ In brief, to be considered as family business in this index, the person(s) that created the company or acquired the company capital, or their relatives have significant influence on the control of the firm. We include a dummy variable 'Family' that is equal to one if the manager has an affiliation to the owner's family and zero otherwise. $^{15}$

With regards to education and overconfidence, Entrop and Merkel (2018) point out that executives in Germany rather hold a $\mathrm{PhD}$ than an MBA degree. As the highest degree in research, a $\mathrm{PhD}$ in continental Europe usually involves both research and teaching and is particulary in German-speaking countries very prestigious. Similar to an MBA, such a superior degree of education may on the one side lead to overconfidence. On the other side, the dissimilar training content compared to an MBA might, according to Entrop and Merkel (2018), foster critical thinking and hence reduce the readiness to assume risk. Thus, the relation between a $\mathrm{PhD}$ and speculation could be positive or negative. We include the dummy variable 'PhD', that equals one if the manager holds a $\mathrm{PhD}$ degree and zero otherwise, as an explanatory variable to investigate its effects alternatively to the variable 'MBA'.

\footnotetext{
12 In relation to family businesses, another point of discussion of the agency theory approach is that it takes financial return as the ultimate goal (maximization of shareholder value), leaving aside the fact that families may derive great benefits which are not easily quantifiable in financial terms, e.g., being in control. Since our sample companies are listed in the CAC All-Tradeable Index, we assume that this aspect is of minor relevance.

13 The authors refer to risk as "the search for new opportunities to increase the firm's performance, taking into consideration unexpected outcomes and performance variance.

14 Euronext is the leading stock exchange in the Eurozone by its own account, and its Family Business Index combines firms from different trading locations in Europe, including our sample firms.

15 We used different channels to collect this data. We first searched the annual reports for relevant information, then reviewed the executive profiles on the corporate websites as well as read information from French newspapers such as Les Échos.
} 
The majority of the literature examines and documents the relevance of CEO characteristics on corporate decision-making (e.g., Beber and Fabbri 2012; Bertrand and Schoar 2003; Doukas and Mandal 2018; King et al. 2016). ${ }^{16}$ Their main argument is that a CEO is ultimately responsible for any corporate practices, including risk management strategies. In contrast, according to Graham and Harvey (2001) the CFO is commonly in charge of all matters related to treasury and risk management. Géczy et al. (2007) also provide survey evidence that CFOs and not CEOs are responsible for the incorporation of speculative motives in risk management decisions. Some studies (e.g., Entrop and Merkel 2018; Géczy et al. 2007) refer to this division of duties and investigate the role of the CFO. Regarding mainly FX risk management policies, Géczy et al. (2007) find that CFO compensation is positively associated with speculation. Following Graham and Harvey (2001) and Géczy et al. (2007), Entrop and Merkel (2018) focus primarily on the CFO's impact on speculation and only include the CEO as robustness check, assuming that in family businesses the CEO determines the risk management strategy. Consistent with this mixed approach in literature, anecdotal evidence from indicative interviews with treasury executives suggest that the influence of the CEO and CFO is companyspecific_-both may influence risk management practices. ${ }^{17}$ Considering all this, we include the above-mentioned variables 'MBA', 'PhD', 'Age', 'Tenure', 'Companies' and 'Family' for both the CEOs and CFOs of our sample firms.

Table 2, Panel A presents descriptive statistics of the managerial characteristics separated by CEO and CFO attributes. The CEO in our sample is on average 55 years old, has an average tenure of 7.8 years and has worked for 2.6 different companies before. Compared to the CEO, the average CFO is younger (49 years) and has less current (5.7 years) and previous (2.4 companies) work experience. Table 2, Panel B illustrates the educational and family background of the executives. $23 \%$ of the CEOs in our sample hold an MBA degree and 13\% a PhD. To illustrate the distribution of these observations across time and firms, the total 388 observations of a CEO with an MBA degree, for example, are evenly distributed over our sample period: We notice between 51 and 79 observations per year, spread between 13 and 19 firms within the 6 years from 2010 to 2015, with overall 9 firms replacing a non-MBA manager by an MBA manager or vice versa. $32 \%$ of the CEOs have an affiliation to the owner family, while for CFOs only $1 \%$ have such a link to the controlling family. In addition, the proportions for an MBA (14\%) or $\mathrm{PhD}(2 \%)$ degree are considerably lower.

\footnotetext{
16 Beber and Fabbri (2012), for example, concentrate on CEO characteristics for corporate speculation, but-for the sake of completeness-incorporate a strongly reduced sample of CFO characteristics due to data limitations.

17 We interviewed four treasury executives of major German corporations, including two DAX-30 firms, to ask for professional judgement. In some firms, the treasurer sees greater influence from the CEO, while in others the CFO is more likely to have an effect on risk management policies.
} 


\subsection{Firm characteristics and other control variables}

Following the extant literature (e.g., Adam et al. 2017; Beber and Fabbri 2012; Géczy et al. 2007), we control for several firm characteristics. The theories for optimal speculation (Adam et al. 2007; Campbell and Kracaw 1999) ${ }^{18}$ illustrate incentives to increase a firm's risk exposure, and show that a firm's profit function that is convex in investment offers an incentive to speculate. Following this convexity of a firm's investment opportunities, positive speculative results allow for profitable investments that would otherwise not be carried out. Campbell and Kracaw (1999) demonstrate that such behavior should be observable with firms that have substantial growth opportunities, modest internal funds as well as high cost of asymmetric information. In line with Adam et al. (2017) and Graham and Harvey (2001), we assume that informational asymmetry affects smaller firms to a much larger extent and hence they are more constrained in external financing. Similar to Adam et al. (2017), we approximate firm size by the logarithm of total assets (log (total assets)) and growth opportunities, in line with Beber and Fabbri (2012), by capital expenditures to total revenues (capex ratio). ${ }^{19}$ Following Beber and Fabbri (2012) and Géczy et al. (2007) we measure liquidity by the quick ratio (cash and short-term investments to total current liabilities) and we approximate leverage similar to Beber and Fabbri (2012) with the debt ratio (total liabilities to total assets).

Similar to the literature (Beber and Fabbri 2012; Doukas and Mandal 2018; Entrop and Merkel 2018), ${ }^{20}$ we further control for the underlying exposure by using the absolute amount of the exposure before hedging standardized by total assets. As new feature of our study, we are able to control for the nature of the exposure: We introduce a dummy variable that equals one if the exposure before hedging is negative and zero otherwise. All variables are defined in "Appendix 3".

Table 2 also reports the descriptive statistics of the firm characteristics and the other control variable, where the different observation numbers are explained by data availabilities in the Compustat Global Vantage database. We also investigate the correlations between the firm and managerial characteristics. Only between the quick and the debt ratio we find a considerable correlation, however the Pearson correlation coefficients are not so high as to represent a problem of multicollinearity.

\footnotetext{
18 According to Stulz (1996), the possession of private information might also lead to speculative positions. However, Stulz (1996) states that such an informational advantage would lead to selective hedging rather than speculative, i.e., risk-increasing practices [see Hecht (2018) for more details]. In addition, non-financial firms do most likely not possess a comparative advantage regarding FX risk management.

${ }^{19}$ Due to potential misinterpretations such as off-balance sheet correlations with speculation, we do not use the book-to-market-ratio (Géczy et al. 2007).

${ }^{20}$ The extant literature does not have access to exposure data and uses foreign sales over total sales as proxy for firm exposure.
} 
Table 2 Descriptive statistics of managerial and firm characteristics

\begin{tabular}{|c|c|c|c|c|c|c|}
\hline & $\mathrm{N}$ & Mean & $\mathrm{SD}$ & Min & p50 & Max \\
\hline \multicolumn{7}{|c|}{ Panel A: managerial and firm characteristics } \\
\hline \multicolumn{7}{|l|}{ CEO characteristics } \\
\hline CEO_Age & 1785 & 55.090 & 6.791 & 34.000 & 55.000 & 73.000 \\
\hline CEO_Tenure & 1785 & 7.834 & 7.534 & 0.000 & 6.000 & 34.000 \\
\hline CEO_Companies & 1737 & 2.593 & 2.052 & 0.000 & 2.000 & 8.000 \\
\hline \multicolumn{7}{|l|}{ CFO characteristics } \\
\hline CFO_Age & 1616 & 49.481 & 6.591 & 35.000 & 49.000 & 64.000 \\
\hline CFO_Tenure & 1734 & 5.671 & 5.280 & 0.000 & 4.000 & 36.000 \\
\hline CFO_Companies & 1754 & 2.403 & 1.603 & 0.000 & 2.000 & 8.000 \\
\hline \multicolumn{7}{|l|}{ Firm characteristics } \\
\hline Log (total assets) & 1805 & 7.926 & 1.613 & 3.063 & 8.086 & 11.142 \\
\hline Debt ratio & 1805 & 0.571 & 0.168 & 0.166 & 0.573 & 1.092 \\
\hline Quick ratio & 1767 & 0.425 & 0.425 & 0.000 & 0.299 & 3.326 \\
\hline Capex ratio & 1766 & 0.052 & 0.068 & 0.000 & 0.038 & 0.748 \\
\hline Exposure & 1805 & 0.023 & 0.050 & 0.000 & 0.006 & 0.794 \\
\hline
\end{tabular}

Panel B: CEO/CFO educational and family background

CEO characteristics

$\begin{array}{lcr}\text { CEO_MBA } & 1671 & 23.22 \\ \text { CEO_PhD } & 1675 & 13.07 \\ \text { CEO_Family } & 1665 & 32.27 \\ \text { CFO characteristics } & & \\ \text { CFO_MBA } & 1153 & 13.99 \\ \text { CFO_PhD } & 1156 & 1.60 \\ \text { CFO_Family } & 1246 & 1.05\end{array}$

This table reports descriptive statistics of the managerial and firm characteristics. Log (total assets) is the logarithm of total assets, the debt ratio captures total liabilities in relation to total assets and the quick ratio captures the sum of cash plus short-term investments divided by total current liabilities. The capex ratio divides the capital expenditures by total revenues. The variable exposure refers to column (d) in "Appendix 1" and is defined as the absolute amount of the exposure before hedging standardized by total assets. All variables are defined in "Appendix 3"

\section{Empirical results}

\subsection{Risk-decreasing versus risk-increasing/-constant strategies}

To investigate the impact of managerial characteristics on the choice of riskdecreasing versus risk-increasing/-constant strategies, we construct a dependent variable that captures both strategic choices according to our hedge ratio classification from Table 1 . This dummy variable 'HR classification' is equal to one 
Table 3 Effect of managerial characteristics on the choice of risk-decreasing versus riskincreasing/-constant strategies

\begin{tabular}{|c|c|c|}
\hline VARIABLES & $(1)$ & (2) \\
\hline \multicolumn{3}{|c|}{ Dependent variable: 'HR classification' } \\
\hline \multirow[t]{2}{*}{$\log$ (total assets) } & $-0.701 *$ & $-1.347 * * *$ \\
\hline & $(0.367)$ & $(0.489)$ \\
\hline \multirow[t]{2}{*}{ Debt ratio } & 1.453 & 1.477 \\
\hline & $(1.380)$ & $(1.481)$ \\
\hline \multirow[t]{2}{*}{ Quick ratio } & -0.440 & -0.422 \\
\hline & $(0.311)$ & $(0.325)$ \\
\hline \multirow[t]{2}{*}{ Capex ratio } & 1.625 & $4.078^{*}$ \\
\hline & $(1.622)$ & $(2.369)$ \\
\hline \multirow[t]{2}{*}{ Exposure } & $-9.508 * * *$ & $-8.529 * * *$ \\
\hline & $(1.834)$ & $(1.813)$ \\
\hline \multirow[t]{2}{*}{ Dummy exposure } & $0.625 * * *$ & $0.519 * * *$ \\
\hline & $(0.158)$ & $(0.168)$ \\
\hline \multirow[t]{2}{*}{ CEO_Age } & & 0.028 \\
\hline & & $(0.027)$ \\
\hline \multirow[t]{2}{*}{ CEO_Tenure } & & -0.016 \\
\hline & & $(0.022)$ \\
\hline \multirow[t]{2}{*}{ CEO_Companies } & & -0.074 \\
\hline & & $(0.103)$ \\
\hline \multirow[t]{2}{*}{ CEO_MBA } & & $1.443^{* *}$ \\
\hline & & $(0.627)$ \\
\hline \multirow[t]{2}{*}{ CEO_Family } & & 0.237 \\
\hline & & $(0.465)$ \\
\hline No. obs. & $1658^{*}$ & $1557 *$ \\
\hline Pseudo R-squared & 0.427 & 0.428 \\
\hline Firm FE & YES & YES \\
\hline
\end{tabular}

This table reports the conditional logistic regression results of our HR classification of FX derivative positions as a function of firm and managerial characteristics. The dependent variable 'HR classification' can take the values 0 [1] for positions classified as risk-decreasing [risk-increasing/-constant] strategies, where risk-decreasing [risk-increasing/-constant] strategies refer to hedging [speculation]. The independent variables are the variables detailed in Table 2 . Log (total assets) is the logarithm of total assets, and the debt ratio captures total liabilities in relation to total assets. The quick ratio is cash, short-term investments and total receivables over total current liabilities, and the capex ratio divides capital expenditures by total revenues. Exposure refers to the absolute amount of the exposure before hedging (column [d] in "Appendix 1") standardized by total assets. Dummy exposure is equal to one if the exposure before hedging is negative and zero otherwise. All models are estimated with firm fixed-effects and cluster-robust standard errors (in parenthesis). *, ** and $* * *$ denote significance at the $10 \%, 5 \%$ and $1 \%$ level, respectively. All variables are defined in "Appendix 3"

*9 groups (108 observations) are dropped due to missing variance in the fixed effects model 
if the hedge ratio per derivative positions indicates risk-increasing/-constant and zero otherwise, i.e., for risk-decreasing strategies.

In Table 3, model (1), we first regress this dummy variable on the set of firm characteristics and the other control variables, which in previous studies have proven to be associated with derivative usage and speculation. In a second step, we add the managerial characteristics of the CEO as additional regressors, including the affiliation to the owner's family. Table 3, model (2) reports the results, where we use firmfixed effects to control for firm-specific characteristics. From the managerial characteristics of the CEO we find the MBA variable to be significant. In line with our hypothesis $\mathrm{H} 1$, the coefficient of the MBA dummy is 1.443 with a statistical significance at the 5\% level, which means that an MBA degree of CEOs is associated with a 1.443 increase in the log-odds of the dependent variable. In other words, firms where the CEO holds an MBA degree are more likely to engage in risk-increasing/constant strategies, i.e., speculation. Similarly, we observe that firms with higher FX exposure tend to use derivatives for risk-decreasing purposes, while firms with a negative exposure are more likely to pursue speculative activities. Regarding the differences of MBA and PhD degrees, we replace the variable CEO_MBA with CEO_ $\mathrm{PhD}$. We find the same positive and statistically significant correlation for $\mathrm{PhD}$ education as for MBA education before (results untabulated).

We perform the same analysis with the CFOs' characteristics, but in contrast to the CEOs we find no significant relationship for the managerial characteristics at all.

One possible explanation for the observed importance of the CEO might be that its role in France differs from the Anglo-Saxon perspective. As the French translation 'Président-Directeur Général' (PDG) illustrates, the chief executive in France combines literally two roles: 'president' and 'general director', or in other words: chairman of the board as well as chief executive. Moreover, the famous dimensions of national culture of Hofstede et al. (2010) and the GLOBE research program ${ }^{21}$ contribute to the more prestigious role of a PDG compared to a CEO. Their power distance index (PDI) deals with the (acceptance of) inequality in a society. For both Hofstede et al. (2010) and the GLOBE research program, the fairly high score of France $^{22}$ for the PDI indicates that people in France accept a hierarchical order without demanding justification for power inequalities. In addition, several studies have demonstrated that superiors in France have certain privileges and are inaccessible in many cases. Further, French firms normally have up to two hierarchical levels more than comparable firms from Germany or the United Kingdom (Barsoux and Löscher 1991; Hofstede et al. 2010; Pitkethly et al. 2000). Taken together, the strong position of the CEO in France might explain its impact on risk management strategies.

\footnotetext{
21 The GLOBE research program by House et al. (2013) builds on data from business leaders and might hence be more relevant. It uses and extends the cultural dimensions defined by Hofstede et al. (2010).

22 According to Hofstede et al. (2010) [the GLOBE research program], France scores with 68 [34] relatively high compared to, for example, the US 40 [13] in the power distance index.
} 


\subsection{The extent of risk-increasing/-constant strategies}

\subsubsection{Company-specific measure}

Further to the dependent variable 'HR classification', we use the data granularity of our dataset and calculate the extent of speculation. So far, the variable 'HR classification' indicates whether hedging instruments are used to decrease, increase of keep the exposure constant. As we further possess the exact exposure per firm, year and currency, we can also calculate how much of the exposure is managed using risk-increasing/-constant strategies ('speculation ratio-firm'). For this purpose, we evaluate the exposure before hedging per position to overall firm exposure, i.e., we determine the value-weighted proportion of speculation per firm and year. This means that a position with an exposure of 0.1 million Euros is not weighted equally as a position with an exposure of 100 million Euros. ${ }^{23}$ The 'speculation ratio-firm' ranges from zero to one and the average for the sample is 0.278 , which indicates that our sample firms speculate with $28 \%$ of their total FX exposure, the median equals 0.072 , the standard deviation 0.360 and the minimum [maximum] is 0.000 [1.000].

In Table 4, models (1) and (2), we re-run the above OLS regression models using the 'speculation ratio-firm' as new dependent variable with firm-fixed effects and cluster-robust standard errors. From model (1) with the firm fundamentals to model (2), where we add the managerial characteristics, the increase of the within $-R^{2}$ by almost $83 \%$ illustrates the relevance of managerial aspects on the choice of riskdecreasing and risk-increasing/-constant strategies. Similar to before, we further observe the CEO_MBA variable to be significant and positively correlated with the extent of speculation. This indicates that firms where the CEO has an MBA degree are more likely to manage their exposure with risk-increasing/-constant derivative transactions. Further and in contrast to our hypothesis $\mathrm{H} 2$, we find a weak and positive reaction for CEO_Age on a 10\% significance level, i.e., firms where the CEO is older also tend to manage their exposure using risk-increasing/-constant strategies.

\subsubsection{Manager-specific measure}

In order to reduce the noise and measure the effects of managerial characteristic on risk management practices even more precisely, we use the unprecedented data granularity of our dataset and set up another model with a new dependent variable. To follow this process, it is important to understand the structure of our data. Assume that a CEO manages a firm over 5 years. Via the registration documents, we possess for this firm and hence CEO multiple observations with FX exposure

\footnotetext{
${ }^{23}$ For example, suppose a firm reports in a year two positions in the recommended format by the AMF as discussed in Sect. 2, one with an exposure before hedging of 2 million Euros, one with exposure before hedging of 8 million Euros (the absolute total FX exposure is thus 10 million Euros). For the position with the exposure of 2 million Euros, the hedge ratio indicates risk-increasing, while the 8 million position is risk-decreasing. The value-weighted share of speculation for the firm (i.e., the "speculation ratio-firm") would accordingly be 0.2 ( 2 million divided by 10 million). Without value weighting, the ratio would be 0.5 (one of two positions is risk-increasing).
} 
information before and after hedging with corresponding hedged amounts. This data enable us to identify how much a $\mathrm{CEO}$ has been engaged in risk-increasing/-constant strategies over 5 years, and hence calculate a CEO-specific speculation ratio. We end up with 87 CEO-specific speculation ratios, which illustrates that our 62 sample firms had on average 1.4 chief executives over our 6-year sample period. With this approach we 'lose' a considerable amount of observations, but the 'lost' observations ended up in the more accurate CEO-specific speculation ratio. Similar to the 'speculation ratio-firm' above, the range of the 'speculation ratio-CEO' goes from zero to one and the average of all CEOs is 0.319 indicating that a CEO speculates with $32 \%$ of its total FX exposure during his tenure. The median of the variable 'speculation ratio-CEO' adds up to 0.170 , the standard deviation to 0.357 and the minimum [maximum] is 0.000 [1.000]. For the CFO, we obtain 85 speculation ratios ranging from zero to one with a mean [median] of 0.343 [0.181], a standard deviation of 0.370 and a minimum [maximum] of 0.000 [1.000].

To re-run the OLS regression models, we also need to calculate the average firm size, debt ratio, quick ratio, capex ratio, exposure as well as the average age and tenure, because, even if a CEO manages a firm over a longer period, these firm and CEO characteristics change every year. Using the 'speculation ratio-CEO' as new dependent in Table 4 models (3) and (4), first of all the increase of the within- $\mathrm{R}^{2}$ from model (3) to model (4) by more than $123 \%$ from 0.139 to 0.310 is striking. Further, the variables CEO_Age and CEO_MBA are again significant with positive correlation coefficients: This evidence confirm the above impression that firms where the CEO is older and holds an MBA degree tend to manage their exposure with risk-increasing/-constant derivative strategies. The remaining managerial characteristics of the CEO_Tenure, CEO_Companies and CEO_Family (hypotheses H3 and $\mathrm{H} 4$, respectively) are not significant in any of the presented models, which suggest that these aspects are not linked to speculative intentions. When we use the CEO_PhD variable instead of CEO_MBA for models (2) and (4), we find again the similar positive and statistically significant relationship (results untabulated). This means that also CEOs with a PhD degree are more likely to manage their exposure using speculative strategies.

Also for these regression models, we replace the CEOs' characteristics with those of CFOs. Similar to before, we do not find any significant relationship for the managerial characteristics.

Overall, our findings relate to the extant literature, in particular to Beber and Fabbri (2012) and Entrop and Merkel (2018), who examine the impact of managerial characteristics on corporate speculation. However, these studies interpret speculation as variation in the derivatives position, not as risk-increasing/-constant activity as we do and thus cannot be directly compared with our study. Beber and Fabbri (2012) focus on the impact of CEOs and find that in firms where the CEO has an MBA degree, is younger, and has worked in fewer companies before, speculation is more prevalent. On the contrary, Entrop and Merkel (2018) focus on the impact of CFOs as well as $\mathrm{PhD}$ education as highly prestigious degree and find that firms where the CFO holds a PhD degree speculate less. Also with MBA education as input variable, the results of Entrop and Merkel (2018) are overall not in line with Beber and Fabbri (2012). This mixed evidence might be the result of country-specific differences 
Table 4 Effect of managerial characteristics on the extent of risk-increasing/-constant strategies

\begin{tabular}{|c|c|c|c|c|}
\hline VARIABLES & (1) & (2) & (3) & (4) \\
\hline \multicolumn{5}{|c|}{$\begin{array}{l}\text { Dependent variable: (1)-(2) 'Speculation ratio-firm' } \\
\text { (3)-(4) 'Speculation ratio-CEO' }\end{array}$} \\
\hline Log (total assets) & $\begin{array}{l}-0.185^{*} \\
(0.107)\end{array}$ & $\begin{array}{l}-0.291 * \\
(0.156)\end{array}$ & $\begin{array}{l}-0.307 \\
(0.188)\end{array}$ & $\begin{array}{l}-0.499 * * \\
(0.228)\end{array}$ \\
\hline Debt ratio & $\begin{array}{l}0.295 \\
(0.271)\end{array}$ & $\begin{array}{l}0.266 \\
(0.253)\end{array}$ & $\begin{array}{l}0.677 \\
(0.576)\end{array}$ & $\begin{array}{l}0.046 \\
(0.613)\end{array}$ \\
\hline Quick ratio & $\begin{array}{l}0.020 \\
(0.057)\end{array}$ & $\begin{array}{l}0.010 \\
(0.054)\end{array}$ & $\begin{array}{l}0.303 \\
(0.327)\end{array}$ & $\begin{array}{l}0.160 \\
(0.340)\end{array}$ \\
\hline Capex ratio & $\begin{array}{l}0.424 \\
(0.421)\end{array}$ & $\begin{array}{l}0.673 \\
(0.506)\end{array}$ & $\begin{array}{l}1.616 \\
(1.231)\end{array}$ & $\begin{array}{l}0.609 \\
(1.612)\end{array}$ \\
\hline Exposure & $\begin{array}{l}0.025 \\
(0.073)\end{array}$ & $\begin{array}{l}-0.007 \\
(0.080)\end{array}$ & $\begin{array}{l}0.158 \\
(0.114)\end{array}$ & $\begin{array}{l}0.290 * * \\
(0.132)\end{array}$ \\
\hline Dummy exposure & $\begin{array}{l}-0.005 \\
(0.011)\end{array}$ & $\begin{array}{l}-0.006 \\
(0.012)\end{array}$ & & \\
\hline CEO_Age & & $\begin{array}{l}0.007^{*} \\
(0.004)\end{array}$ & & $\begin{array}{l}0.007 * \\
(0.004)\end{array}$ \\
\hline CEO_Tenure & & $\begin{array}{l}-0.004 \\
(0.005)\end{array}$ & & $\begin{array}{l}-0.004 \\
(0.004)\end{array}$ \\
\hline CEO_Companies & & $\begin{array}{l}-0.019 \\
(0.014)\end{array}$ & & $\begin{array}{l}0.010 \\
(0.019)\end{array}$ \\
\hline CEO_MBA & & $\begin{array}{l}0.168 * * \\
(0.082)\end{array}$ & & $\begin{array}{l}0.243^{* * * *} \\
(0.071)\end{array}$ \\
\hline CEO_Family & & $\begin{array}{l}0.013 \\
(0.045)\end{array}$ & & $\begin{array}{l}0.054 \\
(0.084)\end{array}$ \\
\hline No. obs. & 1766 & 1665 & 86 & 84 \\
\hline Within R-squared & 0.041 & 0.075 & 0.139 & 0.310 \\
\hline Cluster-robust standard error & YES & YES & YES & YES \\
\hline Firm FE & YES & YES & YES & YES \\
\hline Number of groups & 60 & 58 & 59 & 58 \\
\hline
\end{tabular}

This table reports the regression results of the extent of risk-increasing/-constant, i.e., speculative strategies with FX derivative positions as a function of firm and managerial characteristics. In models (1) and (2), the dependent variable 'speculation ratio-firm' measures the extent of risk-increasing/-constant strategies per firm and year. It ranges from zero to one and indicates for a value of e.g., 0.3 that a firm speculates with $30 \%$ of its FX exposure. The independent variables are the variables detailed in Table 2 . Log (total assets) is the logarithm of total assets, and the debt ratio captures total liabilities in relation to total assets. The quick ratio is cash, short-term investments and total receivables over total current liabilities, and the capex ratio divides capital expenditures by total revenues. Exposure refers to the absolute amount of the exposure before hedging (column [d] in "Appendix 1") standardized by total assets. Dummy exposure is equal to one if the exposure before hedging is negative and zero otherwise. In models (3) and (4), we measure how much a manager has been involved in risk-increasing/-constant strategies over his entire tenure, i.e., the dependent variable 'speculation ratio-CEO' ranges from zero to one and indicates for a value of e.g., 0.3 that a manager speculates with $30 \%$ of the total FX exposure during his tenure. Accordingly, we use for the variables log (total assets), debt ratio, quick ratio, capex ratio, exposure, CEO_Age and CEO_Tenure average values over the term of the manager in models (3) and (4). All models are estimated with firm fixed-effects and cluster-robust standard errors (in parenthesis). *,** and *** denote significance at the $10 \%, 5 \%$ and $1 \%$ level, respectively. All variables are defined in "Appendix 3" 
or potential estimation errors. While the data granularity of our dataset allows us to define hedging [speculation] as risk-decreasing [risk-increasing/-constant] strategy, the extant literature constructs an empirical measure of speculation as firm-specific standard deviation of estimated residuals of a regression with firm characteristics to exclude fundamental hedging motives. Common to these studies is also the application of proxy variables for exposure and derivative usage.

\subsection{Impact of managerial characteristics on derivative usage}

The focus of our study is to shed light on the impact of managerial characteristics on the choice of risk-decreasing and risk-increasing/-constant strategies, i.e., hedging and speculation. The granularity of our dataset allows investigating this hitherto unexamined research question. In addition, we possess unprecedented derivative usage information that enables us to examine how managerial characteristics affect the amount of derivatives used. The latter has typically been used as response variable in various studies (e.g., Beber and Fabbri 2012; Doukas and Mandal 2018; Entrop and Merkel 2018), precisely as the notional amount of FX derivatives scaled by total assets. However, Beber and Fabbri (2012) recognize that the informative value of only notional values, without the indication of the net position, whether it is short or long and in which currency, is limited. Moreover, these studies approximate the FX exposure by foreign sales/total sales. Our new dataset contain exactly the 'missing' information, which allows us to evaluate the impact of managerial characteristics using actually reported information instead of proxy variables with potential estimation errors.

As dependent variable we use the absolute amount of hedging instruments scaled by total assets. This variable 'hedging instruments' counts 1805 observations with a mean of 0.010 , a standard deviation of 0.022 and a minimum [maximum] of 0.000 [0.342]. Rescaling by using only absolute figures converts the range of the variable 'hedging instruments' into an interpretable scale with a minimum of zero and a maximum of infinity. Now, an increase or decrease in hedging instruments is unambiguous, unlike for the previous scale where a decrease in hedging instruments could have been an absolute increase from 100 to -200 units. Further, we are interested in whether the direction of the derivatives affects the amount of hedging instruments, hence we include a dummy variable 'dummy hedging instruments' that is equal to one if the hedging instruments were short, i.e., negative, and zero otherwise. We proceed similarly with the corresponding exposure before hedging: We include the absolute amount of exposure before hedging scaled by total assets, and the dummy variable 'dummy exposure' that is equal to one if the exposure before hedging was negative and zero otherwise as further explanatory variables. The remaining variables are identical to the previous regression models.

Table 5 presents the regression results where-similar to before-we include firm-fixed effects and cluster-robust standard errors, and model (1) regresses the dependent variable on firm fundamentals and model (2) adds the managerial characteristics. We find that the variables CEO_Age, CEO_MBA and CEO_Family are significant with negative correlation coefficients. This means that firms where 
the CEO is older, holds an MBA degree or belongs to the owner's family are more likely to use a lower amount of hedging instruments. The negative correlations for CEO_Age and CEO_MBA match with the positive correlations for the regression models in Tables 3 and 4, where we found that firms with more senior CEOs with an MBA degree tend to manage their exposure with risk-increasing/-constant strategies. Overall, we can state that firms with older CEOs that hold an MBA degree hedge less and speculate more. Further, we observe a negative correlation between the the affiliation to the owner's family and the amount of hedging instruments. According to agency theory, a high degree of firm ownership in the firm might prevent risky activities. Although our finding may be a sign for unhedged positions, we do not conclude that family CEOs tend to take more risks, not least because we do not find significant relationships for family CEOs in the analysis on the choice of risk-decreasing and risk-increasing/-constant strategies. Further, we observe significant and positive correlations for 'dummy hedging instruments', the exposure before hedging and CEO_Tenure. The result for the former variable means that the direction of the hedging instruments indeed matters: When hedging instruments are short, firms tend to use higher volumes. Further, we find that that amount of hedging instruments is more likely to increase when exposure before hedging is higher and when CEOs have longer tenure. Finally, when we insert the CEO_PhD variable instead of CEO_MBA, we find a similar negative and statistically significant relationship.

This evidence on the impact of managerial characteristics on the amount of derivatives used relates particularly to the recent study of Doukas and Mandal (2018). Using proxy variables for the exposure and derivative usage, Doukas and Mandal (2018) examine currency, interest rate and commodity derivatives over a 5-year period and find that CEOs with longer tenure and with more previous work experience tend to hedge more. They also incorporated the age and the MBA education of the chief executives, but did not find any link to derivative usage.

\subsection{Robustness}

To ensure the robustness of our findings we perform additional tests on our various regression analyses. The results in Tables 3 and 4 show already consistent evidence for different models, different dependent variables as well as additional specifications to reduce the noise in measuring the impact of managerial characteristics on corporate risk management. As Sect. 2.1 outlined, the French financial markets' authority advises firms to state their exposure information before and after hedging separately for the concerned currencies. This data granularity opens up the possibility to verify whether different currencies are treated differently, and in our context, whether our results remain unchanged when we further control for the dissimilarities of the currency treatments. Hecht and Lampenius (2019) point out that currencies seem to be hedged heterogeneously: while the exposure in some currencies is reduced or even completely eliminated, the risk in other currencies remains unhedged. Following Hecht and Lampenius (2019), we estimate our OLS regression model with fixed-effects on firm-currency level as additional robustness check. 
Table 5 Effect of managerial characteristics on hedging instruments

\begin{tabular}{|c|c|c|}
\hline VARIABLES & (1) & (2) \\
\hline \multicolumn{3}{|c|}{ Dependent variable: 'Hedging instruments' } \\
\hline Log (total assets) & $\begin{array}{l}0.005^{*} \\
(0.003)\end{array}$ & $\begin{array}{l}0.007 \\
(0.004)\end{array}$ \\
\hline Debt ratio & $\begin{array}{l}-0.013^{* *} \\
(0.005)\end{array}$ & $\begin{array}{l}-0.010^{* *} \\
(0.005)\end{array}$ \\
\hline Quick ratio & $\begin{array}{l}-0.002 \\
(0.001)\end{array}$ & $\begin{array}{l}-0.001 \\
(0.001)\end{array}$ \\
\hline Capex ratio & $\begin{array}{l}0.001 \\
(0.008)\end{array}$ & $\begin{array}{l}-0.010 \\
(0.009)\end{array}$ \\
\hline Exposure & $\begin{array}{l}0.164 * \\
(0.084)\end{array}$ & $\begin{array}{l}0.163^{*} \\
(0.086)\end{array}$ \\
\hline Dummy exposure & $\begin{array}{l}-0.000 \\
(0.002)\end{array}$ & $\begin{array}{l}-0.000 \\
(0.002)\end{array}$ \\
\hline Dummy hedging instruments & $\begin{array}{l}0.004 * * \\
(0.002)\end{array}$ & $\begin{array}{l}0.003 * * \\
(0.002)\end{array}$ \\
\hline CEO_Age & & $\begin{array}{l}-0.000 * * \\
(0.000)\end{array}$ \\
\hline CEO_Tenure & & $\begin{array}{l}0.000 * * * \\
(0.000)\end{array}$ \\
\hline CEO_Companies & & $\begin{array}{l}0.000 \\
(0.000)\end{array}$ \\
\hline CEO_MBA & & $\begin{array}{l}-0.002 * \\
(0.001)\end{array}$ \\
\hline CEO_Family & & $\begin{array}{l}-0.002 * * * \\
(0.001)\end{array}$ \\
\hline No. obs. & 1766 & 1665 \\
\hline Within R-squared & 0.161 & 0.184 \\
\hline Cluster-robust standard error & YES & YES \\
\hline Firm FE & YES & YES \\
\hline Number of groups & 60 & 58 \\
\hline
\end{tabular}

This table reports the regression results of the amount of hedging instruments as a function of firm and managerial characteristics. The dependent variable 'hedging instruments' is defined as the absolute amount of the exposure before hedging [hedging instruments] standardized by total assets. The independent variables are the variables detailed in Table 2. Log (total assets) is the logarithm of total assets, and the debt ratio captures total liabilities in relation to total assets. The quick ratio is cash, short-term investments and total receivables over total current liabilities, and the capex ratio divides capital expenditures by total revenues. Exposure refers to the absolute amount of the exposure before hedging (column [d] in "Appendix 1") standardized by total assets. Dummy exposure [dummy hedging instruments] is equal to one if the exposure before hedging [the net position of hedging instruments] is negative and zero otherwise. All models are estimated with firm fixed-effects and cluster-robust standard errors (in parenthesis). *, ** and *** denote significance at the $10 \%, 5 \%$ and $1 \%$ level, respectively. All variables are defined in "Appendix 3" 
Table 6 Robustness checks

\begin{tabular}{|c|c|c|}
\hline VARIABLES & $(1)$ & (2) \\
\hline \multicolumn{3}{|c|}{ Panel A: robustness choice of risk-decreasing versus risk-increasing/-constant strategies } \\
\hline \multicolumn{3}{|c|}{ Dependent variable: 'HR classification' } \\
\hline Log (total assets) & $\begin{array}{l}-1.004 * * \\
(0.510)\end{array}$ & $\begin{array}{l}-1.577 * * \\
(0.649)\end{array}$ \\
\hline Debt ratio & $\begin{array}{l}2.323 \\
(1.788)\end{array}$ & $\begin{array}{l}2.463 \\
(1.961)\end{array}$ \\
\hline Quick ratio & $\begin{array}{l}-0.793 \\
(0.504)\end{array}$ & $\begin{array}{l}-0.965^{*} \\
(0.552)\end{array}$ \\
\hline Capex ratio & $\begin{array}{l}4.106 \\
(2.597)\end{array}$ & $\begin{array}{l}7.881 * * \\
(3.521)\end{array}$ \\
\hline Exposure & $\begin{array}{l}-13.689 * * * \\
(5.265)\end{array}$ & $\begin{array}{l}-14.683 * * * \\
(5.175)\end{array}$ \\
\hline Dummy exposure & $\begin{array}{l}0.219 \\
(0.261)\end{array}$ & $\begin{array}{l}0.260 \\
(0.281)\end{array}$ \\
\hline CEO_Age & & $\begin{array}{l}0.038 \\
(0.036)\end{array}$ \\
\hline CEO_Tenure & & $\begin{array}{l}-0.030 \\
(0.027)\end{array}$ \\
\hline CEO_Companies & & $\begin{array}{l}0.010 \\
(0.147)\end{array}$ \\
\hline CEO_MBA & & $\begin{array}{l}1.892 * \\
(1.004)\end{array}$ \\
\hline CEO_Family & & $\begin{array}{l}0.654 \\
(0.774)\end{array}$ \\
\hline No. obs. & 666 & 605 \\
\hline Pseudo R-squared & 0.040 & 0.065 \\
\hline Firm-currency FE & YES & YES \\
\hline VARIABLES & (1) & (2) \\
\hline
\end{tabular}

Panel B: Robustness extent of risk-increasing/-constant strategies

Dependent variable: 'Speculation ratio-firm'

Log (total assets)

\begin{tabular}{ll}
$-0.166^{* * *}$ & $-0.262^{* * *}$ \\
$(0.045)$ & $(0.068)$ \\
$0.317 * *$ & $0.300^{* *}$ \\
$(0.124)$ & $(0.118)$ \\
0.020 & 0.006 \\
$(0.027)$ & $(0.025)$ \\
$0.415 * *$ & $0.648^{* * *}$ \\
$(0.161)$ & $(0.192)$ \\
0.064 & -0.055 \\
$(0.284)$ & $(0.290)$ \\
-0.010 & -0.010 \\
$(0.025)$ & $(0.027)$ \\
\hline
\end{tabular}

Debt ratio

$0.317^{* *}$

$0.300 * *$

Quick ratio

Capex ratio

$0.415 * *$

$0.648 * *$

Exposure

(0.161)

(0.192)

0.064

$-0.055$

Dummy exposure

$-0.010$ 
Table 6 (continued)

\begin{tabular}{lll}
\hline VARIABLES & $(1)$ & $(2)$ \\
\hline CEO_Age & & $0.006^{* * * *}$ \\
& & $(0.001)$ \\
CEO_Tenure & & $-0.004^{* * *}$ \\
& & $(0.002)$ \\
CEO_Companies & & $-0.019 * * *$ \\
& & $(0.007)$ \\
CEO_MBA & & $0.154 * * *$ \\
& & $(0.028)$ \\
CEO_Family & & 0.004 \\
No. obs. & & $(0.022)$ \\
Within R-squared & 1766 & 1665 \\
Cluster-robust standard error & 0.035 & 0.065 \\
Firm-currency FE & YES & YES \\
Number of groups & YES & YES \\
\hline
\end{tabular}

This table reports a robustness check of our regression results on the effect of managerial characteristics on (the extent of) risk-decreasing versus risk-increasing/-constant strategies. In Panel A, the dependent variable 'HR classification' can take the values 0 [1] for positions classified as risk-decreasing [riskincreasing/-constant] strategies, where risk-decreasing [risk-increasing/-constant] strategies refer to hedging [speculation]. In Panel B, the dependent variable 'speculation ratio-firm' measures the extent of riskincreasing/-constant strategies per firm and year. It ranges from zero to one and indicates for a value of e.g., 0.3 that a firm speculates with $30 \%$ of its FX exposure. The independent variables are the variables detailed in Table 2. Log (total assets) is the logarithm of total assets, and the debt ratio captures total liabilities in relation to total assets. The quick ratio is cash, short-term investments and total receivables over total current liabilities, and the capex ratio divides capital expenditures by total revenues. Exposure refers to the absolute amount of the exposure before hedging (column [d] in "Appendix 1") standardized by total assets. Dummy exposure is equal to one if the exposure before hedging is negative and zero otherwise. All models are estimated with firm fixed-effects and cluster-robust standard errors (in parenthesis). $* * *$ and $* * *$ denote significance at the $10 \%, 5 \%$ and $1 \%$ level, respectively. All variables are defined in "Appendix 3"

The estimations in Table 6, Panel A and B illustrate that controlling for currency differences does not change our main findings. We still observe that CEO that hold an MBA degree are more likely to engage in speculative strategies. Similarly, the age of a CEO is still statistically significant and positively correlated with the extent of speculation. Further, we observe inconsistent significant reactions concerning the tenure of a CEO as well as the number of companies he has worked for, which could be explained by the stricter specification of the group dummies using firm-currency fixed effects. ${ }^{24}$ Overall, the results in Table 6 confirm our main findings and we deduce that they are not subject to particular currency treatments.

\footnotetext{
${ }^{24}$ For the reduced sample with the CEO-specific speculation ratio, we are unable to perform a robustness check using fixed-effects on firm-currency level due to missing firm-year-currency observations.
} 
Further, we integrate the definition of speculation as selective hedging and focus on the variability of the hedge ratio to evaluate the impact of managerial characteristics on hedge ratio variation. For this purpose and following Hecht and Lampenius (2019), we rescale the hedge ratio (HR) according to

$$
H R_{t}^{*}=\left|1+H R_{t}\right| .
$$

By rescaling, we transform the discontinuous scale, with respect to risk-increasing and risk-decreasing, to a continuous and interpretable scale with a minimum of zero and a maximum of infinity. In contrast to the raw hedge ratio detailed in "Appendix 2", now a decrease [increase] in $H R_{t}^{*}$ denotes an unambiguous decrease [increase] in FX risk exposure.

For $H R_{t}^{*}$, the range between 0 and 1 relates to risk-decreasing while the range between 1 and $\infty$ refers to risk-increasing positions.

Exemplary, a full hedge position $(H R=-1)$ results in $H R_{t}^{*}=0, H R_{t}^{*}=1$ is equal to a zero hedge $(H R=0)$, and $H R_{t}^{*}=1.2$ denotes a $20 \%$ increase in the FX exposure $(H R=0.2)$.

Following the extant literature, we evaluate variation in the derivatives position as the change in $H R_{t}^{*}$ according to ${ }^{25}$

$$
\Delta H R_{t}^{*}=H R_{t}^{*}-H R_{t-1}^{*} .
$$

Table 7 (models 1 and 2) reports the estimates for the OLS regression models with firm-fixed effects and cluster-robust standard errors similar to Table 4, but with $\Delta H R_{t}^{*}$ as new dependent variable. When the CEO has an MBA degree, we find that $\Delta H R_{t}^{*}$ increases, i.e., $H R^{*}$ increases. Thus, management selectively hedges less of its exposure when the CEO holds an MBA degree, which is also interpreted as speculation in the literature. In line with the existing literature and our previous findings using risk-increasing/-constant activities as definition for speculation, our overall results indicate that the management of the FX exposure seems to be impacted by the MBA education of the CEO.

Finally, we employ propensity score matching to mitigate concerns about nonrandom selection (Rosenbaum and Rubin 1983). Following Entrop and Merkel (2018), we examine the differences in the involvement of risk-increasing/-constant activities between CEOs with and without MBA education. To ensure that each matched observation pair is identical except for the MBA education of the CEO, we match firm-years where a CEO holds an MBA degree with firm-years where a CEO does not hold an MBA degree and where no other differences in firm characteristics (Table 2, Panel A) are observed.

Table 8, Panel A reports the results and the differences between the samples matched on the propensity scores. ${ }^{26}$ Similar to the procedure before, we first measure speculation according to our hedge ratio classification from Table 1, i.e.,

\footnotetext{
25 Because $\Delta H R_{t}^{*}$ is created by comparing $H R^{*}$ from the current with the previous period, $\Delta H R_{t}^{*}$ is not available for the first year of our sample period, and we lose around $24 \%$ of our observations.

${ }^{26}$ Both nearest neighbor and kernel matching lead to similar results.
} 
risk-decreasing versus risk-increasing/-constant strategies ('HR classification'). Subsequently, we measure speculation as the extent of risk-increasing/-constant strategies per firm and CEO, i.e., 'Speculation ratio-firm' and 'Speculation ratio-CEO', respectively (Table 4). When analyzing the differences between the matched samples for 'HR classification', we observe that firms in which the CEO has an MBA degree speculate significantly more than firms with non-MBA CEOs, even if multiple other observable characteristics are identical between the firms. Overall, we find that according to all the different definitions of speculation, CEOs with an MBA degree show a higher involvement in speculative activities than CEOs without an MBA degree, where the differences between the matched samples are statistically significant (except for 'Speculation ratio-CEO' with its lower number of observations). ${ }^{27}$ We repeat the same procedure for the age of the CEO as treatment variable (instead of MBA education). For this purpose, we create a dummy variable that is equal to zero [one] when the CEO is younger than or equal to [older than] the average age of 55 years. ${ }^{28}$ As Table 8, Panel B illustrates, we find that firms with older CEOs are more engaged in speculative activities, again according to all our definitions of speculation with similar level of statistical significance as before. ${ }^{29}$ Thus, the propensity score matching outcome essentially confirm our previous results.

\section{Conclusion}

Extant literature demonstrates that managerial characteristics influence a wide range of corporate practices, including risk management. Following the evidence that derivatives are used to decrease and increase risk, we examine the impact of managerial characteristics on the choice of risk-decreasing and risk-increasing/-constant strategies. Based on a hand-collected dataset that contains reported firm-, year-, and currency-specific FX exposures before and after hedging, we are able to separate hedging motives (risk-decreasing) from speculative (risk-increasing/-constant) considerations.

Evaluating both $\mathrm{CEO}$ and $\mathrm{CFO}$ characteristics, we find that the strong positions of a CEO in France influences risk management practices. We provide evidence that firms are more likely to use risk-increasing/-constant strategies when the CEOs is older and has an MBA degree. Based on the unprecedented granularity of our dataset, we develop a metric that allows us to measure the extent to which a particular CEO has been involved in risk-decreasing vs risk-increasing/-constant strategies over several years. Using this precise measure as response variable confirms the positive correlations with the CEO's age as well as MBA education. In addition, we find that firms

\footnotetext{
27 When we use PhD instead of MBA education as treatment variable, we find very similar results (untabulated to avoid redundancies, as before).

${ }^{28}$ The threshold of 55 years corresponds to the average and median age of the CEOs in our sample (Table 2). Further, this limit is in line with the studies of Beber and Fabbri (2012) and Doukas and Mandal (2018).

29 The difference of the matched samples for 'Speculation ratio-CEO is now close to a statistical significance at the $10 \%$ level, however, the number of observations is relatively low.
} 
Table 7 Effect of managerial characteristics on the hedge ratio variation

\begin{tabular}{|c|c|c|}
\hline VARIABLES & (1) & (2) \\
\hline \multicolumn{3}{|l|}{ Dependent variable: $\Delta H R_{t}^{*}$} \\
\hline Log (total assets) & $\begin{array}{l}-3.098 \\
(3.631)\end{array}$ & $\begin{array}{l}-5.385 \\
(5.684)\end{array}$ \\
\hline Debt ratio & $\begin{array}{l}-2.839 \\
(2.596)\end{array}$ & $\begin{array}{l}-2.815 \\
(2.873)\end{array}$ \\
\hline Quick ratio & $\begin{array}{l}1.078 \\
(1.410)\end{array}$ & $\begin{array}{l}1.061 \\
(1.525)\end{array}$ \\
\hline Capex ratio & $\begin{array}{l}2.330 \\
(4.772)\end{array}$ & $\begin{array}{l}6.105 \\
(6.896)\end{array}$ \\
\hline Exposure & $\begin{array}{l}-14.598 \\
(15.073)\end{array}$ & $\begin{array}{l}-15.352 \\
(15.775)\end{array}$ \\
\hline Dummy exposure & $\begin{array}{l}-0.552 \\
(0.339)\end{array}$ & $\begin{array}{l}-0.502 \\
(0.364)\end{array}$ \\
\hline CEO_Age & & $\begin{array}{l}-0.017 \\
(0.140)\end{array}$ \\
\hline CEO_Tenure & & $\begin{array}{l}0.327 \\
(0.197)\end{array}$ \\
\hline CEO_Companies & & $\begin{array}{l}0.914 \\
(0.553)\end{array}$ \\
\hline CEO_MBA & & $\begin{array}{l}12.249 * * \\
(5.723)\end{array}$ \\
\hline CEO_Family & & $\begin{array}{l}-3.266 \\
(2.572)\end{array}$ \\
\hline No. obs. & 1384 & 1308 \\
\hline Within R-squared & 0.002 & 0.005 \\
\hline Cluster-robust standard error & YES & YES \\
\hline Firm FE & YES & YES \\
\hline Number of groups & 60 & 58 \\
\hline
\end{tabular}

This table reports the estimation results of the OLS regression with firm fixed effects as a function of firm and managerial characteristics. The dependent variable is the difference in standardized hedge ratios according to $\Delta H R_{t}^{*}=H R_{t}^{*}-H R_{t-1}^{*}$, with standardization $H R_{t}^{*}=\left|1+H R_{t}\right|$. As a result of the standardization, $H R_{t}^{*}$ can only take positive values from 0 to $\infty$, where the range between 0 and 1 is associated with risk-decreasing and range 1 to $\infty$ represents riskincreasing strategies. The independent variables are the variables detailed in Table 2. Log (total assets) is the logarithm of total assets, and the debt ratio captures total liabilities in relation to total assets. The quick ratio is cash, short-term investments and total receivables over total current liabilities, and the capex ratio divides capital expenditures by total revenues. Exposure refers to the absolute amount of the exposure before hedging (column [d] in "Appendix 1") standardized by total assets. Dummy exposure is equal to one if the exposure before hedging is negative and zero otherwise. All models are estimated with firm fixed-effects and cluster-robust standard errors (in parenthesis). $* * *$ and $* * *$ denote significance at the $10 \%, 5 \%$ and $1 \%$ level, respectively. All variables are defined in "Appendix 3" 
Table 8 Propensity score matching

\begin{tabular}{lllllr}
\hline & Mean (treated) & Mean (control) & Difference & T-Statistics & $\mathrm{N}$ \\
\hline $\begin{array}{l}\text { Panel A: CEO_MBA } \\
\text { 'HR classification' }\end{array}$ & 0.451 & 0.356 & & & \\
'Speculation ratio-firm' & 0.329 & 0.235 & $0.095^{* *}$ & 2.35 & 1665 \\
'Speculation ratio-CEO' & 0.310 & 0.296 & 0.014 & 0.12 & 1665 \\
\hline & Mean (treated) & Mean (control) & Difference & T-Statistics & $\mathrm{N}$ \\
\hline Panel B: CEO_Age & & & & 84 \\
'HR classification' & 0.424 & 0.343 & $0.080^{*}$ & 1.68 & 1766 \\
'Speculation ratio-firm' & 0.310 & 0.243 & $0.068^{* *}$ & 2.06 & 1766 \\
'Speculation ratio-CEO' & 0.354 & 0.210 & 0.144 & 1.46 & 86 \\
\hline
\end{tabular}

This table reports the results of the propensity score matching by comparing the three different specifications previously used for speculation (i.e., risk-increasing/-constant activities) for CEOs with versus without MBA education (Panel A) and for CEOs younger than or equal to versus older than the average age of 55 years (Panel B). The propensity scores are estimated using the firm characteristics specified in Table 2, Panel A. 'HR classification' can take the values 0 [1] for positions classified as risk-decreasing [risk-increasing/-constant] strategies, where risk-decreasing [risk-increasing/-constant] strategies refer to hedging [speculation]. The variable 'speculation ratio-firm' ['speculation ratio-CEO'] measures the extent of risk-increasing/-constant strategies per firm and year [per CEO]. It ranges from zero to one and indicates for a value of e.g., 0.3 that a firm [a manager] speculates with $30 \%$ of the FX exposure [during his tenure]. $*$, ** and $* * *$ denote significance at the $10 \%, 5 \%$ and $1 \%$ level, respectively. All variables are defined in "Appendix 3"

where the CEO is affiliated to the owner's family tend to use fewer derivatives in FX hedging, whereas firms seem to use higher derivative volumes when hedging short.

Overall, our findings extend the existing empirical literature on the impact of managerial characteristics on risk management practices, because we define speculation not as variation in the derivatives position but as risk-increasing/-constant activity. Without the usage of proxy variables for the exposure and derivative usage, we are able to determine speculative activities using publicly available reported information and contribute to the literature when relating this new perspective of speculation to managerial characteristics. Since our access to executive compensation data was restricted, future research may want to consider its role in the choice of risk-decreasing and riskincreasing/-constant strategies.

Acknowledgments We thank the editor and the anonymous reviewers for their careful reading of our manuscript and their many insightful comments and suggestions. We gratefully acknowledge access to Bloomberg and the Compustat Global Vantage database provided by DALAHO, University of Hohenheim. We especially thank Dirk Hachmeister, Niklas Lampenius and Alina Sigel for extensive discussions and valuable feedback, as well as Carolin Eigenthaler, Ruben Kuhnle, Marc-Philip Eckermann and Louis Prinz for their support in data collection.

Funding Open Access funding enabled and organized by Projekt DEAL. 
Open Access This article is licensed under a Creative Commons Attribution 4.0 International License, which permits use, sharing, adaptation, distribution and reproduction in any medium or format, as long as you give appropriate credit to the original author(s) and the source, provide a link to the Creative Commons licence, and indicate if changes were made. The images or other third party material in this article are included in the article's Creative Commons licence, unless indicated otherwise in a credit line to the material. If material is not included in the article's Creative Commons licence and your intended use is not permitted by statutory regulation or exceeds the permitted use, you will need to obtain permission directly from the copyright holder. To view a copy of this licence, visit http://creativecommons.org/licen ses/by/4.0/.

\section{Appendix 1: Template of information requested in the registration document}

\begin{tabular}{|c|c|c|c|c|c|c|}
\hline Year & Assets* [a] & $\begin{array}{l}\text { Liabilities* } \\
{[\mathrm{b}]}\end{array}$ & $\begin{array}{l}\text { Forecasted } \\
\text { exposure } \\
(\text { sales }(+) \\
\text { and pur- } \\
\text { chases }(-)) \\
\text { [c] }\end{array}$ & $\begin{array}{l}\text { Exposure } \\
\text { before hedg- } \\
\text { ing }[d]=[a] \\
-[b]+[c]\end{array}$ & $\begin{array}{l}\text { Hedging } \\
\text { instruments } \\
(\text { long }(+) \text { and } \\
\text { short }(-))[e]\end{array}$ & $\begin{array}{l}\text { Exposure } \\
\text { after hedging } \\
{[\mathrm{f}]=[\mathrm{d}]+[\mathrm{e}]}\end{array}$ \\
\hline Currency 1 & 120 & 30 & 10 & 100 & -50 & 50 \\
\hline \multicolumn{7}{|l|}{ Currency 2} \\
\hline \multicolumn{7}{|l|}{ Currency n } \\
\hline Total & $\ldots$ & $\ldots$ & $\ldots$ & $\ldots$ & $\ldots$ & $\ldots$ \\
\hline
\end{tabular}

This table presents the recommendations, including a numerical example currency position, detailed by the supervisor of the French financial markets, Autorité des Marchés Financiers (AMF), in position paper $\mathrm{n}^{\circ}$ 2009-16. In this guideline document, the AMF has established a so-called 'registration document', which as optional supplement, aims at providing additional information regarding risk management of foreign exchange exposure for various stakeholders. The original document is in French language and not available in English

*Mostly in form of FX-trade receivables and FX-trade payables, respectively

\section{Appendix 2: Hedge ratio properties}

\begin{tabular}{lcccccc}
\hline & $\begin{array}{c}\text { Risk- } \\
\text { increasing } \\
\text { strategy }\end{array}$ & $\begin{array}{c}\text { Risk- } \\
\text { decreasing } \\
\text { strategy }\end{array}$ & $\begin{array}{c}\text { Risk- } \\
\text { decreasing } \\
\text { strategy }\end{array}$ & $\begin{array}{c}\text { Risk- } \\
\text { increasing } \\
\text { strategy }\end{array}$ & $\begin{array}{c}\text { Risk- } \\
\text { constant } \\
\text { strategy }\end{array}$ & $\begin{array}{c}\text { Risk- } \\
\text { constant } \\
\text { strategy }\end{array}$ \\
\hline Hedge ratio range & & & & & & \\
\hline Exposure before hedging [d] & 100 & 100 & 100 & 100 & 100 & 100 \\
Hedging instruments [e] & -250 & -150 & -50 & 50 & -200 & 0 \\
Exposure after hedging [f] & -150 & -50 & 50 & 150 & -100 & 100 \\
\hline Hedge ratio (HR $=[\mathrm{e}] /[\mathrm{d}])$ & -2.5 & -1.5 & -0.5 & 0.5 & -2 & 0 \\
\hline HR: & $+\infty$ & -2 & -1 & 0 & $\infty$ & \\
\hline
\end{tabular}


This table illustrates properties of the hedge ratio $(H R)$ and contains a numerical illustration to demonstrate the combination of FX exposure before hedging (denominator) and the hedging instruments (numerator) in the hedge ratio using the column references introduced in "Appendix 1". For illustrative purposes we assume as base scenario a firm with an exposure before hedging in a particular currency of 100 units, i.e., $E^{b}=100$. That firm can now take one out of six exemplary, fundamentally different positions that differ in the amount of hedging instruments $(H)$ and the resulting exposure after hedging $\left(\mathrm{E}^{a}\right)$, where two of the six positions result in a decrease in risk, two in an increase in risk and two keep the risk at a constant level. Further, it illustrates the hedge ratio range given the six fundamentally different positions

\section{Appendix 3: Definition of variables}

\begin{tabular}{|c|c|}
\hline Variables & Description of variables \\
\hline \multicolumn{2}{|l|}{ Firm and other variables } \\
\hline Capex ratio & Capital expenditures/total revenues \\
\hline Debt ratio & Total liabilities/total assets \\
\hline Dummy exposure & $\begin{array}{l}\text { Dummy variable that is equal to one if the exposure before hedging is } \\
\text { negative and zero otherwise }\end{array}$ \\
\hline Dummy hedging instruments & $\begin{array}{l}\text { Dummy variable that is equal to one if the net position of hedging instru- } \\
\text { ments is negative and zero otherwise }\end{array}$ \\
\hline$E_{t}^{b}(\cdot)$ & Exposure before hedging in $t$ \\
\hline Exposure & $\begin{array}{l}\text { Absolute amount of the exposure before hedging standardized by total } \\
\text { assets }\end{array}$ \\
\hline$H_{t}(\cdot)$ & Hedging instruments in $t$ \\
\hline Hedging instruments & Absolute amount of hedging instruments standardized by total assets \\
\hline$H R_{t}$ & $\begin{array}{l}\text { Hedge ratio with } H R_{t}=H_{t} / \mathrm{E}_{t}^{b} \text { percentage of } \mathrm{FX} \text { exposure covered by } \\
\text { financial instruments }\end{array}$ \\
\hline$H R^{*}$ & $H R_{t}^{*}=\left|1+H R_{t}\right|$ \\
\hline$\Delta H R^{*}$ & $\Delta H R_{t}^{*}=H R_{t}^{*}-H R_{t-1}^{*}$ \\
\hline Quick ratio & $($ Cash + short-term investments $) /$ Total current liabilities $)$ \\
\hline Speculation ratio-firm & $\begin{array}{l}\text { This variable measures the extent of risk-increasing/-constant strategies } \\
\text { per firm and year on a metric scale from } 0 \text { to } 1 \text {, where a value of } 0.3 \\
\text { indicates that a firm speculates with } 30 \% \text { of its FX exposure }\end{array}$ \\
\hline \multicolumn{2}{|l|}{ Managerial variables } \\
\hline Age & Age of the manager in years \\
\hline Companies & $\begin{array}{l}\text { Number of companies the manager has worked before joining the current } \\
\text { company }\end{array}$ \\
\hline Family & $\begin{array}{l}\text { Dummy variable that is equal to one if the manager has family ties to the } \\
\text { owner's family and zero otherwise }\end{array}$ \\
\hline MBA & $\begin{array}{l}\text { Dummy variable that is equal to one if the manager holds an MBA degree } \\
\text { and zero otherwise }\end{array}$ \\
\hline Speculation ratio-CEO/CFO & $\begin{array}{l}\text { This variable measures the extent of risk-increasing/-constant strategies } \\
\text { per CEO/CFO over his entire tenure on a metric scale from } 0 \text { to } 1 \text {, } \\
\text { where a value of } 0.3 \text { indicates that a CEO/CFO speculates with } 30 \% \text { of } \\
\text { the total FX exposure during his tenure }\end{array}$ \\
\hline Tenure & Number of years that the manager holds his position \\
\hline
\end{tabular}




\section{References}

Adam T, Dasgupta S, Titman S (2007) Financial constraints, competition, and hedging in industry equilibrium. J Finance 62(5):2445-2473. https://doi.org/10.2139/ssrn.550021

Adam T, Fernando C, Golubeva E (2015) Managerial overconfidence and corporate risk management. J Bank Finance 60:195-208. https://doi.org/10.1016/j.jbankfin.2015.07.013

Adam T, Fernando C, Salas J (2017) Why do firms engage in selective hedging? Evidence from the gold mining industry. J Bank Finance 77:269-282. https://doi.org/10.1016/j.jbank fin.2015.05.006

Albouy M, Dupuy P (2017) Selective hedging of foreign exchange risk: new evidence from French nonfinancial firms. Management International 21(4):76-88

Allayannis G, Ofek E (2001) Exchange rate exposure hedging and the use of foreign currency derivatives. J Int Money Finance 20:273-296

Autorité des Marchés Financiers (2009) Position-recommandation AMF n ${ }^{\circ}$ 2009-16: Guide d'élaboration des documents de référence. Accessed from https://www.amf-france.org/fr/reglementa tion/doctrine/doc-2009-16. Accessed 22 Dec 2020

Barsoux J-L, Löscher P (1991) The making of a French manager. Harvard Bus Rev 69(July-August):58-67

Beber A, Fabbri D (2012) Who times the foreign exchange market? Corporate speculation and CEO characteristics. J Corp Finance 18(5):1065-1087. https://doi.org/10.1016/j.jcorpfin.2012.07.004

Bertrand M, Schoar A (2003) Managing with style: the effect of managers of firm policies. Q J Econ CXVIII(4):1169-1208

Bodnar GM, Marston RC, Hayt G (1998) Survey of financial risk management by U.S. non-financial firms. Financ Manag 27(Winter):113-133

Campbell TS, Kracaw WA (1999) Optimal speculation in the presence of costly external financing. In: Brown GW, Chew DH (eds) Corporate risk management. Risk Books, London, pp 131-139

Doukas JA, Mandal S (2018) CEO risk preferences and hedging decisions: a multiyear analysis. J Int Money Finance 86:131-153

Entrop O, Merkel MF (2018) Managers' research education, the use of FX derivatives and corporate speculation. Rev Manag Sci. https://doi.org/10.1007/s11846-018-0314-Z

Fama EF (1970) Efficient capital markets: a review of theory and empirical work. J Finance 25(2):383-417

Fama EF, Jensen MC (1983) Separation of ownership and control. J Law Econ 26(2):301-325

Géczy CC, Minton BA, Schrand C (2007) Taking a view: corporate speculation, governance, and compensation. J Finance LXII(5):2405-2444. https://doi.org/10.1111/j.1540-6261.2007.01279.X

Gervais S, Odean T (2001) Learning to be overconfident. Rev Financ Stud 14(1):1-27

Giambona E, Graham JR, Harvey CR, Bodnar GM (2018) The theory and practice of corporate risk management: evidence from the field. Working Paper, pp 1-56. Accessed from https://papers.ssrn.com/ sol3/papers.cfm?abstract_id=3143797

Glaum M (2002) The determinants of selective hedging-evidence from German non-financial corporations. J Appl Corp Finance 14(4):108-121

Graham JR, Harvey CR (2001) The theory and practice of corporate finance: evidence from the field. J Financ Econ 60:187-243

Hambrick DC, Mason PA (1984) Upper echelons: the organization as a reflection of its top managers. Acad Manag Rev 9(2):193-206

Hecht A (2018) Identifying corporate speculation reading public disclosures—why firms increase risk (Under review). Accessed from https://papers.ssrn.com/sol3/papers.cfm?abstract_id=3001668

Hecht A (2019) How do firms manage their interest rate exposure? J Risk Finance 20(5):501-519

Hecht A, Lampenius N (2019) How do firms manage their foreign exchange exposure? J Appl Corp Finance. (Under review). Accessed from https://papers.ssrn.com/sol3/papers.cfm?abstract_ id $=2987901$

Hentschel L, Kothari SP (2001) Are corporations reducing or taking risks with derivatives? J Financ Quant Anal 36(1):93-118. https://doi.org/10.2307/2676199

Hofstede G, Hofstede GJ, Minkov M (2010) Cultures and organizations: software of the mind, 3rd edn. McGraw-Hill, New York

House RJ, Dorfman PW, Javidan M, Hanges PJ, de Sully Luque M (2013) GLOBE book 3: strategic leadership across cultures. SAGE Publications, Inc., London 
Hull JC (2015) Options, futures and other derivatives, vol 9. Pearson, London. https://doi.org/10.1017/ CBO9781107415324.004

Huybrechts J, Voordeckers W, Lybaert N (2013) Entrepreneurial risk taking of private family firms: the influence of a nonfamily CEO and the moderating effect of CEO tenure. Family Bus Rev 26(2):161179. https://doi.org/10.1177/0894486512469252

Jensen MC, Meckling WH (1976) Theory of the firm: managerial behavior, agency costs and ownership structure. J Financ Econ 3:305-360

King T, Srivastav A, Williams J (2016) What's in an education? Implications of CEO education for bank performance. J Corporate Finance 37(C):287-308

Malmendier U, Tate GA (2005) CEO overconfidence and corporate investment. J Finance 60(6):2661-2700

Malmendier U, Tate GA, Yan J (2011) Overconfidence and early-life experiences: the effect of managerial traits on corporate financial policies. J Finance 66(5):1687-1733

Pitkethly R, Faulkner D, Child J (2000) National differences in acquisition intergration. In: Faulkner D, De Rond M (eds) Cooperative strategy: economic, business, and organizational issues. Oxford Unversity Press, Oxford, pp 283-306

Rosenbaum PR, Rubin DB (1983) The central role of the propensity score in observational studies for causal effects. Biometrika 70(1):41-55

Shleifer A, Vishny RW (1989) Managerial entrenchment: the case of manager-specific investments. J Financ Econ 25(1):123-139

Stulz RM (1996) Rethinking risk management. J Appl Corp Finance 9(3):8-24. https://doi. org/10.1111/j.1745-6622.1996.tb00295.x

Tufano P (1996) Who manages risk? An empirical examination of risk management practices in the gold mining industry. J Finance 51(4):1097-1137. https://doi.org/10.1111/j.1540-6261.1996.tb04064.x

Zahra SA (2005) Entrepreneurial risk taking in family firms. Family Bus Rev 18:23-40

Zhang H (2009) Effect of derivative accounting rules on corporate risk-management behavior. J Acc Econ 47(3):244-264. https://doi.org/10.1016/j.jacceco.2008.11.007

Publisher's Note Springer Nature remains neutral with regard to jurisdictional claims in published maps and institutional affiliations. 